\title{
DEBAR YOMYCES POLYMORPHUS VAR. AFRICANUS, A NEW VARIETY OF ASCOSPOROGENOUS YEAST FOUND IN SOUTH AFRICA
}

\author{
JOHANNES P. VAN DER WALT, TAKASHI NAKASE, ${ }^{1, *}$ MOTOFUMI SUZUKI, ${ }^{1}$ \\ MASAKO TAKASHIMA, ${ }^{1}$ AND YUZO YAMADA ${ }^{2}$ \\ Department of Microbiology and Biochemistry, Faculty of Science, The University of \\ the Orange Free State, 339 Bloemfontein 9300, South Africa \\ ${ }^{1}$ Japan Collection of Microorganisms, The Institute of Physical and Chemical Research \\ (RIKEN), Wako 351-01, Japan \\ ${ }^{2}$ Laboratory of Applied Microbiology, Department of Agricultural Chemistry, \\ Shizuoka University, Shizuoka 422, Japan
}

(Received June 29, 1994; Accepted August 15, 1994)

Two strains of the genus Debaryomyces, that are phenotypically and genetically close to D. polymorphus, were isolated from South African soils. Nuclear DNA comparison studies established that the two strains reassociate with the type strain of $D$. polymorphus for $49-59 \%$. The two strains have consequently been assigned to the new variety $D$. polymorphus var. africanus which is practically distinguished from $D$. polymorphus var. polymorphus by the utilization of L-rhamnose.

Two strains of an ascosporogenous yeast isolated from soils collected in South Africa were found to show characteristics similar to those of Debaryomyces polymorphus, but differentiated from this species by the utilization of L-rhamnose. DNA-DNA reassociation determinations revealed that these two isolates represent a new variety of Debaryomyces polymorphus. The new taxon is described in the present paper.

\section{MATERIALS AND METHODS}

Strains employed. Two strains, JCM 7442 (=CBS 6742) and JCM 7443 (=CBS 6741) were used in the present study. These strains were isolated from South African soil collected near Lydenburg and Graskop, respectively. Debaryomyces polymorphus (9) JCM 3647 (=CBS 186, type strain) and Debaryomyces pseudopolymorphus (9) JCM 3652 (=CBS 2008, type strain) were used for the

* Address reprint requests to: Dr. Takashi Nakase, Japan Collection of Microorganisms, The Institute of Physical and Chemical Research (RIKEN), 2-1 Hirosawa, Wako, 351-01, Japan. 
comparative study. DNAs from Candida parapsilosis JCM 1785 (=CBS 604, type strain) and calf thymus were used as the reference in the DNA-DNA reassociation experiments.

Investigation of taxonomic criteria. Most of the methods used for the investigation of morphological, physiological and biochemical characteristics were those described by van der Walt and Yarrow (12). Assimilation of nitrogen compounds was investigated on solid media with starved inoculum. The vitamin requirement was investigated according to Komagata and Nakase (1). The maximum growth temperature was determined in YM broth using metal block baths.

Transmission electron microscopy. Observations by transmission electron microscope (TEM) were based on ascigerous material from a 10-day-old culture of JCM 7443 on YM agar, fixed in aqueous $1.5 \%$ potassium permanganate as described by van der Walt and von Arx (11).

Investigation of chemotaxonomic criteria. Extraction and purification of ubiquinones were carried out according to Nakase and Suzuki (8) using cells harvested in the stationary phase. Ubiquinone isoprenologues were identified by high performance liquid chromatography (HPLC).

DNAs were isolated and purified according to Nakase and Suzuki (6). The DNA base composition was analyzed by HPLC after the hydrolysis of DNA according to the procedure reported by Suzuki (10) as described in a previous paper (5). The DNA-DNA reassociation experiments were carried out by the membrane filter technique as previously reported (6).

Determination of the partial sequence of $18 S$ rRNA. The rRNA was isolated and purified according to the procedure reported by Yamada and Kawasaki (13). The partial sequence of 18S rRNA was determined according to the method of Lane et al. (3) using reverse transcriptase. The oligonucleotide DNA primer used in the experiment was $5^{\prime}$-ACGGGCGGTGTGTAC-3' which is complementary to the sequence of the positions (in Saccharomyces cerevisiae) 1641 through 1627 of 18S rRNA (4, GenBank J01353D, M27607).

\section{RESULTS AND DISCUSSION}

The two yeast isolates obtained from South African soil have Q-9 as the major component of ubiquinone isoprenologues (Table 1), and produce ascospores with warty walls. These properties are diagnostic features of the genus Debaryomyces. In the taxonomic criteria commonly employed, these isolates resemble Debaryomyces polymorphus and Debaryomyces pseudopolymorphus. The $\mathrm{G}+\mathrm{C}$ content of nuclear DNA of these two isolates showed a value of $32.5-33.0 \mathrm{~mol} \%$ which was close to those of $D$. polymorphus and $D$. pseudopolymorphus, 31.8 and 31.7 mol\%, respectively (Table 2). In the DNA-DNA reassociation experiment, these two isolates showed low relatedness to $D$. pseudopolymorphus, and intermediate relatedness of $50-59 \%$ (at $60^{\circ} \mathrm{C}$ ) and $49-56 \%$ (at $70^{\circ} \mathrm{C}$ ) to D. polymorphus. In comparisons of DNA relatedness and fertility, DNA relatedness of $65-70 \%$ or 
greater suggests strains to be conspecific in most cases (2). The value of $49-56 \%$ or $50-59 \%$ indicates a close relationship of strains but is too low to regard them as conspecific. So, we decided to deal with these two isolates as a new variety of $D$. polymorphus, as done by Nakase and Suzuki $(6,7)$ in the case of Debaryomyces hansenii. It consequently proposed to subdivide $D$. polymorphus as follows:

1. Debaryomyces polymorphus (Klöcker) Price et Phaff 1979 var. polymorphus.

2. Debaryomyces polymorphus (Klöcker) Price et Phaff var. africanus van der Walt, Nakase et Suzuki, var. nov.

In extracto malti post triduum ad $25^{\circ} \mathrm{C}$ cellulae vegetativae ellispoideae, ovoideae vel botuliformes, $2.0-9.0 \times 2.0-6.5 \mu \mathrm{m}$, singulae, binae raro aggregatae. Pellicula hebes repens annulus et sedimentum formantur.

In agaro malti post unum mensem ad $17^{\circ} \mathrm{C}$, cultura butyrosa, cremea, patens, glabra, striata transverse tenuiter, margine integro vel undulato aliquando lobato. In agaro farina Zeae maydis post dies 10 ad $25^{\circ} \mathrm{C}$ hyphae et pseudophyphae nullae. Asci per automixi, ovoidei, ellipsoidei vel elongati, 3.0-14.0 $\times 2.0-5.0 \mu \mathrm{m}$, sparse per fusionem cellularum duarum discretarum, 1-2 spori, persistentes. Ascosporae

Table 1. Ubiquinone systems of strains of Debaryomyces polymorphus var. africanus and related yeasts.

\begin{tabular}{llcccc}
\hline \multirow{2}{*}{ Strain } & & \multicolumn{3}{c}{ Molar ratio of ubiquinones (\%) } \\
\cline { 3 - 5 } & & Q-7 & Q-8 & Q-9 & Q-10 \\
\hline D. polymorphus var. africanus & JCM 7442 & 0.8 & 10.4 & 88.6 & 0.2 \\
& JCM 7443 & 0.8 & 7.2 & 91.5 & 0.5 \\
D. polymorphus var. polymorphus & JCM 3647 & Trace & 2.6 & 96.9 & 0.5 \\
D. pseudopolymorphus & JCM 3652 & Trace & 6.4 & 93.4 & 0.2 \\
\hline
\end{tabular}

T, type strain.

Table 2. DNA relatedness among strains of Debaryomyces polymorphus var. africanus, Debaryomyces polymorphus var. polymorphus and Debaryomyces pseudopolymorphus.

\begin{tabular}{|c|c|c|c|c|c|c|}
\hline \multirow{3}{*}{ Source of unlabeled DNA } & & \multirow{3}{*}{$\begin{array}{c}\mathrm{Mol} \% \\
\mathrm{G}+\mathrm{C} \\
\text { of DNA }\end{array}$} & \multicolumn{4}{|c|}{$\%$ Relative binding of DNA } \\
\hline & & & \multicolumn{2}{|c|}{$\begin{array}{c}\text { D. polymorphus } \\
\text { var. africanus } \\
\text { JCM } 7443^{\mathrm{T}}\end{array}$} & \multicolumn{2}{|c|}{$\begin{array}{l}\text { D. polymorphus } \\
\text { var. polymorphus } \\
\text { JCM } 3647^{\mathrm{T}}\end{array}$} \\
\hline & & & $60^{\circ} \mathrm{C}$ & $70^{\circ} \mathrm{C}$ & $60^{\circ} \mathrm{C}$ & $70^{\circ} \mathrm{C}$ \\
\hline \multirow[t]{2}{*}{ D. polymorphus var. africanus } & JCM 7442 & 33.0 & 100 & 100 & 59 & 56 \\
\hline & JCM $7443^{\mathrm{T}}$ & 32.5 & 93 & 92 & 55 & 53 \\
\hline D. polymorphus var. polymorphus & JCM $3647^{\mathrm{T}}$ & 31.8 & 50 & 49 & 100 & 100 \\
\hline D. pseudopolymorphus & $\mathrm{JCM} 3652^{\mathrm{T}}$ & 31.7 & 24 & 23 & 26 & 25 \\
\hline Candida parapsilosis & JCM $1785^{\mathrm{T}}$ & 38.0 & 6 & 6 & 9 & 9 \\
\hline Calf thymus & & & 1 & 0 & 0 & 1 \\
\hline
\end{tabular}

\footnotetext{
T, type strain.
} 


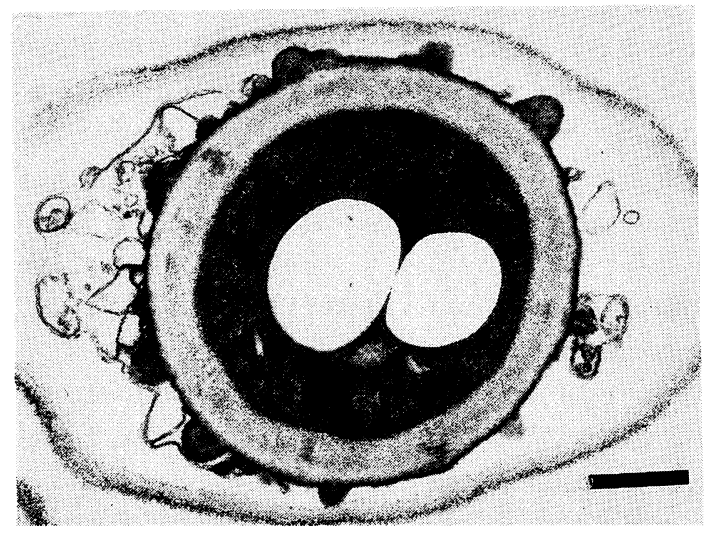

Fig. 1. Debaryomyces polymorphus var. africanus.

TEM micrograph showing the electron-dense warty surface structure of the ascospore. The bar represents $0.5 \mu \mathrm{m}$.

maturae globosae, diam. 1.5-3.0 $\mu \mathrm{m}$, verruculosae, brunnea, olei continentes.

Glucosum, galactosum (lente et exiguum), sucrosum, maltosum (lente, vel lente et exiguum) et raffinosum fermentantur at non trehalosum nec lactosum.

D-Glucoso, D-galactoso, L-sorboso, sucroso, maltoso, cellobioso (lente), trehaloso, lactoso (lente vel nullo), melibioso, raffinoso, melezitoso, inulino, amylo solubile, D-xyloso, L-arabinoso (lente), D-arabinoso (lente), D-riboso, L-rhamnoso, ethanolo, ribitolo, galactitolo, D-mannitolo, D-glucitolo, $\alpha$-methyl-D-glucosido, salicino (fortasse lente), acido 2-ketogluconico, acido 5-ketogluconico, D-glucosamino (lente), $\mathrm{N}$-acetyl-D-glucosamino, hexadecano, acido DL-lactico (lente et exiguo, vel nullo), acido succinico et acido citrico utitur, at non methanolo, acido Dglucuronico, acido D-galacturonico, acido saccharico nec inositolo.

Maxima temperatura crescentiae: $39-42^{\circ} \mathrm{C}$. Ad crescentiam vitaminae non necessariae sunt. Materia amyloidea iodophila non formatur. Non color ruber Sale Diazonii Cerulei B formans. Proportio molaris guanini + cytosini in acido deoxyribonucleinico: $32.5-33.0$ (per HPLC). Ubiquinonum majus: Q-9.

Holotypus: Cultura JCM 7443, a J. P. van der Walt e terra prope Graskop (Africa australis) isolata et in collectione culturarum "Japan Collection of Microorganisms (Wako, Saitama, Japonia)" conservatur.

Growth in malt extract: After 3 days at $25^{\circ} \mathrm{C}$, cells are ellipsoid, ovoid to botuliform, 2.0-9.0 $\times 2.0-6.5 \mu \mathrm{m}$, and occur singly, in pairs, rarely in aggregates. A dull, creeping pellicle, ring and sediment are formed.

Growth on malt agar: After 4 weeks at $17^{\circ} \mathrm{C}$, the culture is butyrous, cream-colored, spreading, smooth with faint transverse striations, and with an entire, undulating, occasionally lobate margin.

Formation of ascospores: Asci arising from the conjugation of a mother-cell and bud, are ellipsoid, ovoid to elongate, 3.0-14.0 $\times 2.0-5.0 \mu \mathrm{m}$, one- to two-spored (usually one-spored), and persistent(Fig. 1). Conjugation of independent cells is 
less common. Mature ascospores are globose, 1.5-3.0 $\mu \mathrm{m}$ in diameter, verruculose, and contain lipid globules. Actively sporulating cultures are light brown.

Dalmau plate culture on corn meal agar: After 10 days at $25^{\circ} \mathrm{C}$, neither hyphae nor pseudohyphae are formed. Chains of cells may, however, be produced under the coverslip.

Fermentation:

\begin{tabular}{|c|c|c|c|}
\hline Glucose & & Trehalose & - \\
\hline Galactose + & (latent and weak) & Lactose & - \\
\hline Sucrose & & Raffinose & + \\
\hline Maltose & (latent, or latent a & d weak) & \\
\hline Jtilization of car & rbon compounds: & & \\
\hline D-Glucose & + & Ribitol & + \\
\hline D-Galactose & + & Galactitol & + \\
\hline L-Sorbose & + & D-Mannitol & + \\
\hline Sucrose & + & D-Glucitol & + \\
\hline Maltose & + & $\alpha$-Methyl-D-glucoside & + \\
\hline Cellobiose & + (latent) & Salicin & + (may be \\
\hline Trehalose & + & & latent) \\
\hline Lactose & + (latent) or - & D-Gluconate & + \\
\hline Melibiose & + & Glucono- $\delta$-lactone & + \\
\hline Raffinose & + & 2-Ketogluconic acid & + \\
\hline Melezitose & + & 5-Ketogluconic acid & + \\
\hline Inulin & + & D-Glucuronic acid & - \\
\hline Soluble starch & + & D-Galacturonic acid & - \\
\hline D-Xylose & + & D-Glucosamine & + (latent) \\
\hline L-Arabinose & + (latent) & N-Acetyl-D-glucosamine & + \\
\hline D-Arabinose & + (latent) & Hexadecane & + \\
\hline D-Ribose & + & DL-Lactic acid & + (latent and \\
\hline L-Rhamnose & + & & weak) or - \\
\hline Ethanol & + & Succinic acid & + \\
\hline Methanol & - & Citric acid & + \\
\hline Glycerol & + & Saccharic acid & - \\
\hline Erythritol & + & Inositol & - \\
\hline
\end{tabular}

Assimilation of nitrogen compounds:

Ammonium sulfate + Ethylamine hydrochloride +

Potassium nitrate - $\quad$ L-Lysine hydrochloride +

Sodium nitrite - $\quad$ Cadaverine dihydrochloride -

Maximum growth temperature: $39-42^{\circ} \mathrm{C}$.

Vitamins required: None.

Production of starch-like substances: Absent.

Urease: Absent.

Liquefaction of gelatin: Absent.

Hydrolysis of fat: Absent. 
Growth on 50\% glucose-yeast extract agar: Weak.

Growth on 60\% glucose-yeast extract agar: Absent.

Growth in $10 \% \mathrm{NaCl}+5 \%$ glucose medium: Positive.

Acid production on chalk agar: Absent.

Cycloheximide resistance (1,000 ppm): Positive.

Diazonium Blue B color reaction: Absent.

$\mathrm{G}+\mathrm{C}$ content of nuclear DNA: $32.5-33.0 \mathrm{~mol} \%$ (by HPLC).

Major ubiquinone system: Q-9.

Holotype strain: JCM 7443 (=CBS 6741) isolated from soil collected near Graskop (South Africa).

Etymology: africanus L. adj. african, which refers to the habitat of the new variety.

Practically, $D$. polymorphus var. africanus is distinguished from $D$. polymorphus var. polymorphus by the utilization of L-rhamnose, and from $D$. pseudopolymorphus by the utilization of inulin and D-arabinose, and the absence of any vitamin requirement.

In positions 1451 through 1618 (in Saccharomyces cerevisiae) of 18S rRNA, Debaryomyces polymorphus var. africanus has the identical nucleotide sequences to a group of Debaryomyces including $D$. castellii, $D$. polymorphus var. polymorphus, D. pseudopolymorphus, $D$. vanrijiae var. vanrijiae, $D$. vanrijiae var. yarrowii, $D$. yamadae, and Yamadaea philogaea (14). The sequence data of D. polymorphus var. africanus JCM 7443 and JCM 7442 will appear in the DDBJ, EMBL and GenBank Nucleotide Sequence Database with the numbers D31790 and D31791, respectively.

\section{REFERENCES}

1) Komagata, K. and Nakase, T., Reitoshokuhin no biseibutsu ni kansuru kenkyu. V. Shihan reitoshokuhin yori bunri shita kobo no seijo (Microbiological studies on frozen foods. V. General properties of yeasts isolated from frozen foods) (in Japanese). Shokuhin Eiseigaku Zasshi, 8, 5357 (1967).

2) Kurtzman, C. P., Prediction of biological relatedness among yeasts from comparisons of nuclear DNA complementarity. Stud. Mycol., 30, 459-468 (1987).

3) Lane, D. J., Pace, B., Olson, G. J., Stahl, D. A., Sogin, M. L., and Pace, N. R., Rapid determination of $16 \mathrm{~S}$ ribosomal RNA sequences for phylogenetic analysis. Proc. Natl. Acad. Sci. U.S.A., 82, 6955-6959 (1985).

4) Mankin, A. S., Skryabin, K. G., and Rubtsov, P. M., Identification of ten additional nucleotides in the primary structure of yeast 18S rRNA. Gene, 44, 143-145 (1986).

5) Nakase, T., Itoh, M., Takematsu, A., Mikata, K., Banno, I., and Yamada, Y., Kockovaella, a new ballistospore-forming anamorphic yeast genus. J. Gen. Appl. Microbiol., 37, 175-197 (1991).

6) Nakase, T. and Suzuki, M., Taxonomic studies on Debaryomyces hansenii (Zopf) Lodder et Kreger-van Rij and related species. I. Chemotaxonomic investigations. J. Gen. Appl. Microbiol., 31, 49-69 (1985).

7) Nakase, T. and Suzuki, M., Taxonomic studies on Debaryomyces hansenii (Zopf) Lodder et Kreger-van Rij and related species. II. Practical discrimination and nomenclature. J. Gen. Appl. Microbiol., 31, 71-86 (1985). 
8) Nakase, T. and Suzuki, M., The ubiquinone system in strains of species in the ballistosporeforming yeast genera Sporidiobolus, Sporobolomyces and Bullera. J. Gen. Appl. Microbiol., 32, 251258 (1986).

9) Price, C. W. and Phaff, H. J., Debaryomyces polymorphus and D. pseudopolymorphus, new taxonomic combinations. Mycologia, 71, 444-445 (1979).

10) Suzuki, K., Kakusan no bunseki. I. DNA enki sosei. In Atarashii bunrui-gaku ni bansou suru saikin no doutei ho: Hyogen keishitsu no kan-i shiken kara kakusan no bunseki made (The analysis of nucleic acids. I. DNA base composition. In Bacterial Identification in Accordance with Recent Taxonomy: Use of Phenotypic, Chemical, and Genetic Analysis) (in Japanese), ed. by The Education Committee, Japanese Society for Bacteriology, Saikon Publ., Tokyo (1987), p. 88-97.

11) van der Walt, J. P. and von Arx, J. A., The septal ultrastructure of Hormoascus ambrosiae and the emendation of the genus Hormoascus. Syst. Appl. Microbiol., 6, 90-92 (1985).

12) van der Walt, J. P. and Yarrow, D., Methods for the isolation, maintenance, classification and identification of yeasts. In The Yeasts, A Taxonomic Study, 3rd ed., ed. by Kreger-van Rij, N. J. W., Elsevier Sci. Publ., Amsterdam (1984), p. 45-105.

13) Yamada, Y. and Kawasaki, H., The molecular phylogeny of the $\mathrm{Q}_{8}$-equipped basidiomycetous yeast genera Mrakia Yamada et Komagata and Cystofilobasidium Oberwinkler et Bandoni based on the partial sequences of $18 \mathrm{~S}$ and $26 \mathrm{~S}$ ribosomal ribonucleic acids. J. Gen. Appl. Microbiol., 35, 173-183 (1989).

14) Yamada, Y., Nagahama, T., and Banno, I., The molecular phylogeny of the Q9-equipped ascomycetous teleomorophic yeast genus Debaryomyces Lodder et Kreger-van Rij based on the partial sequences of $18 \mathrm{~S}$ and $26 \mathrm{~S}$ ribosomal ribonucleic acids. J. Gen. Appl. Microbiol., 37, 277-288 (1991). 